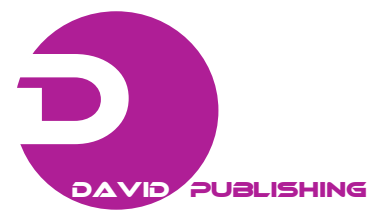

\title{
Cultivation of Candida utilis on Cassava Peel Hydrolysates for Single-cell Protein Production
}

\author{
Olufunke O. Ezekiel ${ }^{1}$, Ogugua C. Aworh ${ }^{1}$, James C. du Preez ${ }^{2}$ and Laurinda Steyn ${ }^{2}$ \\ 1. Department of Food Technology, University of Ibadan, Ibadan, Nigeria \\ 2. Department of Microbial, Biochemical and Food Biotechnology, University of the Free State, Bloemfontein, South Africa
}

Received: February 13, 2012 / Published: August 20, 2012.

\begin{abstract}
The growth of Candida utilis NRRL Y-1084 in acid and enzymatic hydrolysates of cassava peel and on glucose in a mineral salts medium was investigated in aerobic submerged cultivation. Kinetic and stoichiometric parameters for growth were determined. The cardinal temperatures of this yeast strain were $14{ }^{\circ} \mathrm{C}, 33{ }^{\circ} \mathrm{C}$ and $41{ }^{\circ} \mathrm{C}$. C. utilis exhibited no absolute requirement for growth factors, although its maximum specific growth rate $\left(\mu_{\max }\right)$ was higher in the mineral salts medium with yeast extract than without, but its biomass yield coefficient $\left(\mathrm{Y}_{\mathrm{x} / \mathrm{s}}\right)$ did not differ much in these two media. In the enzymatic hydrolysate, its $\mathrm{Y}_{\mathrm{x} / \mathrm{s}}$ value on sugar was 0.44 with a $\mu_{\max }$ of $0.35 \mathrm{~h}^{-1}$, whereas the corresponding values were 0.52 and $0.48 \mathrm{~h}^{-1}$ in the acid hydrolysate and 0.50 and $0.37 \mathrm{~h}^{-1}$ in the mineral salts medium without yeast extract. The crude protein content of biomass grown in the glucose medium and the acid and enzymatic hydrolysates were $47.5 \%, 49.1 \%$ and $56.7 \%$, respectively. The amino acid profile of the yeast biomass compared favourably with the FAO standard. Cassava peel hydrolysate has potential as a cheap carbohydrate feedstock for the production of yeast single cell protein by using C. utilis.
\end{abstract}

Key words: Candida utilis, yeast, cassava peel hydrolysate, amino acid profile, single-cell protein (SCP).

\section{Introduction}

Single cell protein (SCP) refers to the microbial biomass, or proteins extracted from there, obtained from processes in which bacteria, yeasts, filamentous fungi or algae are cultivated in large quantities as a protein supplement in animal feed or in human nutrition [1]. The protein can be consumed directly as part of the cells, particularly in animal feed formulations, or it can be extracted and processed into fibres or meat-like products for nutritious human food [2]. SCP, unlike the production of conventional plant and animal protein resources, does not require agricultural land and is not limited by sunlight because the micro-organisms can be grown in large bioreactor vessels or other suitable large scale cultivation systems. Other advantages of SCP production include the high

Corresponding author: Olufunke O. Ezekiel, Ph.D., research fields: food processing and food biotechnology. E-mail: funkeawoyele@yahoo.com. growth rate of microbial cells, their ease of genetic manipulation and the high protein content of micro-organisms. Furthermore, SCP can be produced from a wide range of substrates, including agricultural and industrial wastes that constitute serious environmental problems.

Micro-organisms have the ability to upgrade low protein plant material to high protein feed [3]. Large scale utilization of methanol, starch and molasses as carbon feedstocks has proved economically viable for the production of animal feed and human food [4-6]. A continuous aerobic process has been successfully used for the production of SCP from cheese whey using the yeast Kluyveromyces fragilis [7-11]. In another instance, the suitability of deproteinized sweet and sour cheese whey concentrates as substrates for the production of SCP with Kluyveromyces marxianus was investigated [12]. Analysis of the amino acid composition of the SCP showed a distinct increase in 
eight out of ten essential amino acids compared to sweet and sour protein and exceeded the World Health Organization (WHO) guideline for valine, leucine, isoleucine, threonine, phenylalanine and tyrosine [12].

Yeasts are a rich source of not only proteins but also B-complex vitamins. They have been used as a supplement in animal feed to compensate the amino acid and vitamin deficiencies of cereals and are recommended as a substitute for soybean oil in diets for fowls [13]. It has been shown that the common carp can obtain a high portion of its dietary protein from the yeasts Candida tropicalis, C. utilis and C. lipolytica, with better results than with soybean or meat and bone meals [14]. In addition, yeast biomass is considered a cheap dietary supplement as it is easily produced on industrial scale from a number of by-products such as citrus pulp, molasses, paper industry wastes and fruit waste, as well as from hydrocarbons. Despite their vast potential, however, the use of yeast biomass as a protein source is not extensive and has been limited largely to the feeding of molluscs and as live feed in aquaculture [15]. Apparently sulphur amino acid deficiency restricts the use of yeasts, though there may also be other factors limiting their use, such as their high carbohydrate and nucleotide content [16].

Interest in the recovery of waste or by-products have been increasing for both economic and ecological reasons as well as for nutritional reasons [17]. In the last two decades in Nigeria there have been concerted efforts in finding ways of complete utilization of agro-industrial by-products, which sometimes constitute environmental hazards [18]. Cassava (Manihot esculenta Crantz syn. Manihot utilissima Pohl), a staple food of the majority of people in tropical Africa, Central and South America [19, 20], is subjected to various fermentations in the different countries to produce similar or different products [21]. In Brazil, Costa Rica and Bolivia, farina is often the end product, whereas in tropical Africa gari, fufu, lafun, chiwangue and myondo are produced from cassava [20, 22]. The various production processes are usually accompanied by some waste products that act as environmental pollutants [23]. Cassava peels, leaves and starch residues constitute $25 \%$ of the cassava plant [18]. These are usually discarded as wastes after harvesting and processing, with limited utilization due to their low protein, high crude fibre and cyanide contents [24]. The peel amounts to about $10 \%-20 \%$ of the root mass and is available all year round in Nigeria with an annual yield of approximately 4 million metric tonnes from the processing of cassava roots [25]. Little attention has been paid to the handling of the large quantity of cassava wastes that are generated. SCP production is a potential route for converting such wastes to a useful and valuable product.

The objectives of this study were to determine the growth kinetics of C. utilis in acid and enzymatic hydrolysates of cassava peel and to evaluate the chemical composition and amino acid profile of the resultant biomass with a view to its utilization as a food or feed protein supplement.

\section{Materials and Methods}

\subsection{Micro-organism and Culture Medium}

Candida utilis NRRL Y-1084 was obtained from the culture collection of the Department of Microbial, Biochemical and Food Biotechnology, University of the Free State, South Africa and maintained on glucose peptone yeast extract (GPY) agar slants. The chemically defined mineral salts culture medium comprised (per L.): $5 \mathrm{~g}$ glucose, $0.25 \mathrm{~g}$ citric acid, $2 \mathrm{~g}$ $\left(\mathrm{NH}_{4}\right)_{2} \mathrm{SO}_{4}, 6.8 \mathrm{~g} \mathrm{KH}_{2} \mathrm{PO}_{4}, 0.2 \mathrm{~g} \mathrm{MgSO}_{4} \cdot 7 \mathrm{H}_{2} \mathrm{O}, 0.01 \mathrm{~g}$ $\mathrm{CaCl}_{2} \cdot 2 \mathrm{H}_{2} \mathrm{O}, 0.1 \mathrm{~g} \mathrm{NaCl}$ and $1 \mathrm{~mL}$ of a trace element solution according to du Preez and van der Walt [26]. In some cultivations, yeast extract (Bacto Yeast Extract, Difco, Detroit) was added to this medium as indicated in the text. The medium was adjusted to $\mathrm{pH} 6.0$ with 3 $\mathrm{M} \mathrm{KOH}$ before autoclaving.

\subsection{Hydrolysis of the Cassava Peel Starch}

The peel from fresh cassava tubers, variety TME I, were obtained from a farm in Ajibade village in the 
Akinyele local government area, Ibadan, Nigeria. Acid hydrolysis of the cassava peel starch was performed by using the optimized method described by Woiciechowski et al. [27] for cassava bagasse with slight modification. A $1 \%$ solution $(\mathrm{v} / \mathrm{v})$ of hydrochloric acid was used to hydrolyse the cassava peel for $10 \mathrm{~min}$ at $121{ }^{\circ} \mathrm{C}$. Following centrifugation at 4,000 rpm for $15 \mathrm{~min}$, the supernatant was collected and the $\mathrm{pH}$ adjusted to 5.0 with $\mathrm{KOH}$ pellets prior to inoculation

Enzymatic hydrolysis was performed by using Termamyl $120 \mathrm{~L} \alpha$-amylase (Novo Industry $\mathrm{A} / \mathrm{S}$, Bagsvaerd, Denmark) for liquefaction, at a concentration of $0.06 \%$ on starch dry weight (equivalent to $0.036 \%(\mathrm{w} / \mathrm{w})$ on dry peel weight) according to the manufacturer's dosage recommendation. Saccharification was done with Novo AMG 300 L amyloglucosidase, using a concentration of $0.15 \%$ on starch dry weight. One liter volume of the dried and milled cassava peel was added to distilled water to give a suspension of about $5 \%$ peel on dry weight ( $8 \%$ moisture content), which was subsequently adjusted to $\mathrm{pH} 6.5$ with $3 \mathrm{M} \mathrm{KOH}, 8 \mathrm{mg}$ $\mathrm{L}^{-1}$ of $\mathrm{Ca}^{2+}\left(0.029 \mathrm{~g} \mathrm{~L}^{-1}\right.$ of $\left.\mathrm{CaCl}_{2} \cdot 2 \mathrm{H}_{2} \mathrm{O}\right)$ added and then heated to $92.5{ }^{\circ} \mathrm{C}$ in a boiling water bath. The Termamyl was added to the slurry when the temperature approached $60{ }^{\circ} \mathrm{C}$. After liquefaction, the temperature was decreased to $60{ }^{\circ} \mathrm{C}$ and the $\mathrm{pH}$ adjusted to 4.5 with $3 \mathrm{~N} \mathrm{H}_{2} \mathrm{SO}_{4}$ prior to addition of the AMG. Hydrolysis was allowed to proceed for $9 \mathrm{~h}$ with stirring. Samples, taken at $1 \mathrm{~h}$ intervals, were immediately boiled to inactivate the AMG whereas trichloroacetic acid was added to a final concentration of $5 \%(\mathrm{v} / \mathrm{v})$ to inactivate the Termamyl.

\subsection{Shake Flask Cultivation of C. utilis}

The growth of C. utilis was evaluated in $500 \mathrm{~mL}$ Erlenmeyer flasks with cotton wool plugs containing $50 \mathrm{~mL}$ medium, the composition of which is given above. Each flask was inoculated with a loopful of yeast culture from a $24 \mathrm{~h}$ agar slant and incubated at
$30{ }^{\circ} \mathrm{C}$ on a rotary shaker at $180 \mathrm{rpm}$. Growth was monitored by optical density measurement by using a Photolab S6 photometer (WTW, Weilheim, Germany) at $690 \mathrm{~nm}$. The dry biomass concentration was determined by centrifuging $5 \mathrm{~mL}$ of the culture sample, washing with distilled water and drying to constant weight at $105^{\circ} \mathrm{C}$.

\subsection{Bioreactor Cultivation of C. utilis in Cassava Peel Hydrolysates}

Batch cultivations of C. utilis in acid and enzymatic cassava peel hydrolysates were conducted at $30{ }^{\circ} \mathrm{C}$ in a 2 L Multigen F-2000 bioreactor (New Brunswick Scientific, Edison, New Jersey, USA) and a 2 L Labfors 3 bioreactor (Infors AG, Bottmingen-Basel, Switzerland) with an $800 \mathrm{~mL}$ working volume. The $\mathrm{pH}$ was controlled at $\mathrm{pH} 5.0$ by automatic titration with 3 $\mathrm{M} \mathrm{KOH}$ and $3 \mathrm{~N} \mathrm{H}_{2} \mathrm{SO}_{4}$. The dissolved oxygen tension (DOT) was maintained above $30 \%$ of saturation by manual (Multigen bioreactor) or automatic (Labfors bioreactor) adjustment of the agitation speed and air flow rate. Foaming was controlled by adding $0.4 \mathrm{~mL}$ $\mathrm{L}^{-1}$ of a $20 \%(\mathrm{v} / \mathrm{v})$ solution of Dow Corning 1510 silicone antifoam (Dow Corning Europe S.A., Seneffe, Belgium) to the medium at a concentration of $0.4 \mathrm{~mL}$ $\mathrm{L}^{-1}$. Samples were taken at regular intervals for analyses. Cultivation in the mineral salts medium with glucose was used as control for comparative purposes.

The maximum specific growth rate $\left(\mu_{\max }\right)$ of the batch culture was determined from the slope of the exponential phase the growth curve by linear regression analysis using Microsoft Excel. The maximum volumetric rate of substrate (total carbohydrate) utilization $\left(\mathrm{Q}_{\mathrm{s}}{ }^{\mathrm{max}}\right)$ was calculated from the maximum slope of the substrate concentration curve plotted as a function of time, according to:

$$
Q_{s}^{\max }=\frac{s_{1}-s_{2}}{t_{2}-t_{1}}
$$

where $s_{1}$ and $s_{2}$ were the substrate concentrations at time $t_{1}$ and $t_{2}$, respectively. The maximum volumetric rate of product formation $\left(\mathrm{Q}_{\mathrm{p}}{ }^{\mathrm{max}}\right)$ was similarly 
calculated from the maximum slope of the curve of product concentration vs. time:

$$
Q_{p}{ }^{\max }=\frac{P_{2}-P_{1}}{t_{2}-t_{1}}
$$

where $P_{1}$ and $P_{2}$ were the yeast protein concentrations at time $t_{1}$ and $t_{2}$, respectively. The biomass yield coefficient $\left(\mathrm{Y}_{\mathrm{x} / \mathrm{s}}\right)$ was calculated as:

$$
Y_{x / s}=\frac{x_{t}-x_{o}}{s_{o}-s_{t}}
$$

where $x_{0}$ and $s_{0}$ were the initial biomass and substrate (total carbohydrate) concentrations, respectively, and $x_{t}$ and $s_{t}$ were the corresponding concentrations when the highest biomass concentration was reached. The product (yeast protein) yield coefficient $\left(\mathrm{Y}_{\mathrm{p} / \mathrm{s}}\right)$ was similarly calculated as:

$$
Y_{p / s}=\frac{p_{t}-p_{o}}{s_{o}-s_{t}}
$$

where $p_{t}$ and $s_{t}$ were the protein and substrate concentrations, respectively, when the highest biomass protein concentration was reached.

2.5 Determination of the Cardinal Temperatures of C. utilis

The cardinal temperatures of C. utilis were determined by using a temperature gradient incubator (Scientific Industries Inc., New York, USA) consisting of an aluminium bar that was cooled at one end and heated at the other to obtain a stable temperature gradient, following a procedure described previously [28]. The bar contained 30 equidistant sample wells on both sides into which L-shaped tubes of optically selected glass $(40 \mathrm{~mL}$ total volume and $17 \mathrm{~mm}$ in diameter) were inserted and capped with loose-fitting metal caps. Whereas tubes on the one side contained yeast cultures, the corresponding tubes on the other side contained water to allow accurate measurement of the temperature in each of the corresponding tubes. The bar rocked through a $30^{\circ}$ arc at 60 oscillations $\mathrm{min}^{-1}$, thereby providing mixing and aeration. The sterile culture tubes, each containing $10 \mathrm{~mL}$ autoclaved culture medium, were equilibrated at the appropriate temperature for $12 \mathrm{~h}$ prior to inoculation with $0.1 \mathrm{~mL}$ from a $12 \mathrm{~h}$ shake flask culture of $C$. utilis. Growth was monitored by determination of the optical density using a Biowave C0800 cell density meter (Walden Precision Apparatus Ltd., Cambridgeshire, UK) at $600 \mathrm{~nm}$ by removing the tubes sequentially at $30 \mathrm{~min}$ intervals without stopping the shaker.

The maximum specific growth rate $\left(\mu_{\max }\right)$ at each temperature was determined by linear regression analysis of the $\ln$ OD vs. time growth curves. An Arrhenius model was applied to describe the linear relationship between the specific growth rate and temperature:

$$
\mu_{\max }=\mathrm{A} \mathrm{e}^{-(\mathrm{E} / \mathrm{RT})}
$$

where $\mu_{\max }$ is the maximum specific growth rate, $\mathrm{A}$ is an entropy constant, $\mathrm{E}$ the temperature coefficient (activation energy), $\mathrm{R}$ the universal gas constant (8.314 J $\mathrm{mol}^{-1} \mathrm{~K}^{-1}$ ), and $\mathrm{T}$ the absolute temperature in $\mathrm{K}$ [29]. On taking natural logarithms, the above equation becomes:

$$
\ln \mu_{\max }=\ln \mathrm{A}-(\mathrm{E} / \mathrm{R}) \frac{1}{\mathrm{~T}}
$$

The value of $\mathrm{E}$ was derived from the slope of the plot of $\ln \mu_{\max }$ vs. $1 / T$, and the value of $A$ was found from the intercept.

\subsection{Analytical Methods}

Yeast protein was determined by using the biuret method [30]. The crude protein content (total Kjeldahl nitrogen $\times 6.25$ ), the content of crude fibre (determined by using acid and alkali treatment), lipids (by Soxhlet petroleum ether extraction), ash $\left(600^{\circ} \mathrm{C}\right.$ for $\left.3 \mathrm{~h}\right)$, and total carbohydrates (estimated by difference) were quantified according to the AOAC methods [31]. The total cyanide content of dried samples was determined by phosphoric acid extraction and hydrolysis of cyanogenic glucosides with linamarase from cassava, followed by the colorimetric determination of cyanide [32]. The amino acid analysis of the yeast biomass was carried out by using a Beckman 6300 amino acid analyser (Beckman Instruments Corp., Palo Alto, CA). The chemical score of the biomass product was calculated following the method of FAO/WHO [33] by 
using the formula:

Chemical score $=$

mg primary limiting amino acid per $\mathrm{g}$ test protein $\times 100$

$\mathrm{mg}$ same amino acid per $\mathrm{g}$ reference protein

\section{Results and Discussion}

\subsection{Shake Flask Cultivation of C. utilis}

To determine the requirement of $C$. utilis for growth factors, the yeast was grown in the mineral salts medium without and with yeast extract (Fig. 1 and Table 1). The presence of yeast extract enhanced the maximum specific growth rate significantly, even though the biomass yield coefficients $\left(\mathrm{Y}_{\mathrm{x} / \mathrm{s}}\right)$ differed little in the two media. These yields were similar to those previously reported $[34,35]$. As the cultivation proceeded, the $\mathrm{pH}$ of both media decreased. The decrease in $\mathrm{pH}$ was less in the medium containing yeast extract, presumably due to its buffering effect. These results indicated that $C$. utilis NRRL Y-1084 had no absolute requirement for growth factors, as it grew exponentially to almost the same biomass concentration as in the medium containing yeast extract, albeit at a somewhat lower growth rate (Table 1). Consequently, the cultivation of C. utilis in cassava peel hydrolysates was carried out without the inclusion of yeast extract. This would reduce the cost of the bioprocess for producing SCP.

\subsection{Cardinal Temperatures of C. utilis}

Fig. 2 shows the maximum specific growth rate $\left(\mu_{\max }\right)$ of $C$. utilis as a function of the cultivation temperature. The optimum temperature range was in the region of $32{ }^{\circ} \mathrm{C}$ to $35^{\circ} \mathrm{C}$ with a $\mu_{\max }$ value of $0.46 \mathrm{~h}^{-1}$ recorded at $33{ }^{\circ} \mathrm{C}$. These growth rates were within the range of 0.4 to $0.6 \mathrm{~h}^{-1}$ reported by others for this yeast species [36, 37]. The minimum and maximum temperatures, obtained by extrapolation, were approximately $14{ }^{\circ} \mathrm{C}$ and $41^{\circ} \mathrm{C}$, respectively.

The Arrhenius plot of these data is shown in Fig. 3. The inflection points in Fig. 3 indicate changes in the temperature coefficient $(\mathrm{E})$, the values of which are shown in Table 2. These data indicate that within the range of $17.6{ }^{\circ} \mathrm{C}$ to $29.1{ }^{\circ} \mathrm{C}$ the growth rate of C. utilis was more sensitive to an increase in temperature than within the range from $29.1{ }^{\circ} \mathrm{C}$ to $33.0^{\circ} \mathrm{C}$. Above $33.0^{\circ} \mathrm{C}$ the high negative value of the temperature coefficient indicated a rapid decrease in the growth

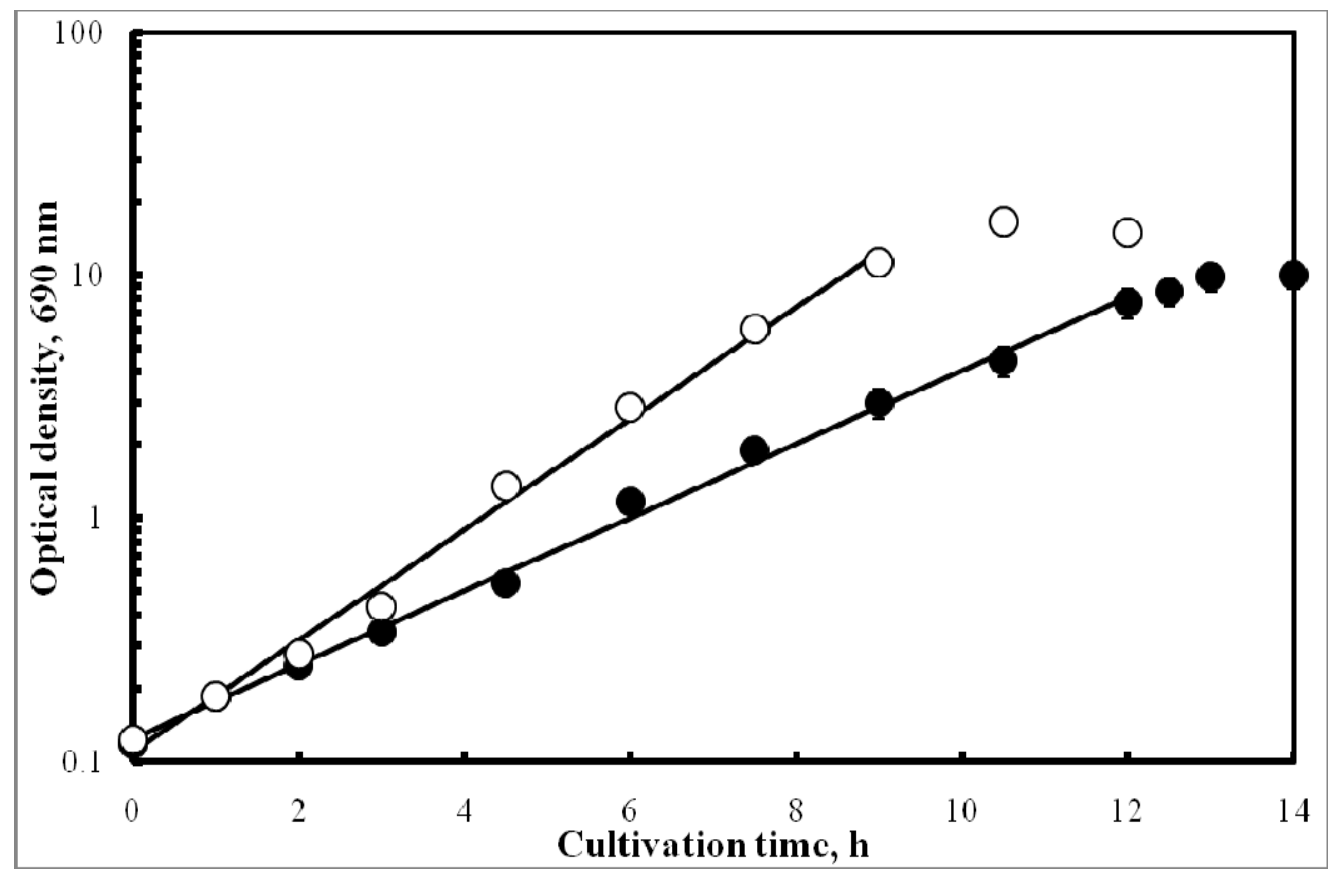

Fig. 1 Growth curves of $C$. utilis in a mineral salts medium with $(\circ)$ and without $(\bullet)$ supplementation with yeast extract. 
Table 1 Cultivation parameters of $C$. utilis in a mineral salts medium with and without supplementation with yeast extract.

\begin{tabular}{lll}
\hline Parameter & \multicolumn{1}{l}{ With yeast extract } & Without yeast extract \\
\hline$\mu_{\max } / \mathrm{h}^{-1}$ & $0.54( \pm 0.00)$ & $0.37( \pm 0.01)$ \\
Dry biomass $/ \mathrm{g} \mathrm{L}^{-1}$ & $2.54( \pm 0.1)$ & $2.50( \pm 0.09)$ \\
$\mathrm{Y}_{\mathrm{x} / \mathrm{s}}$ & $0.51( \pm 0.02)$ & $0.50( \pm 0.02)$ \\
Initial $\mathrm{pH}$ & $6.00( \pm 0.1)$ & $6.00( \pm 0.1)$ \\
Final pH & $5.74( \pm 0.1)$ & $4.17( \pm 0.1)$ \\
\hline
\end{tabular}

Each value is the mean of three independent experiments, with the standard deviation of the mean indicated in parentheses.

Table 2 Temperature coefficient of $C$. utilis in different temperature ranges.

\begin{tabular}{lccl}
\hline $\begin{array}{l}\text { Temperature } \\
\text { range }\left({ }^{\circ} \mathrm{C}\right)\end{array}$ & $\begin{array}{l}\text { Slope } \\
\text { curve }\end{array}$ & $\begin{array}{c}\text { of Correlation } \\
\text { coefficient }\end{array}$ & $\begin{array}{l}\text { Temperature } \\
\text { coefficient }\left(\mathrm{kJ} \mathrm{mol}^{-1}\right)\end{array}$ \\
\hline $17.6-29.1$ & $-9,355$ & 0.97 & 77.8 \\
$29.1-33.0$ & $-3,464$ & 0.99 & 28.8 \\
$32.5-41.3$ & $+41,069$ & 0.96 & -341.5 \\
\hline
\end{tabular}

rate with increasing temperature. Subsequent cultivations of $C$. utilis were conducted at $30.0^{\circ} \mathrm{C}$, which was also the temperature used by others [34, 38], seeing that the temperature coefficient was the lowest within the temperature range from $29.1^{\circ} \mathrm{C}$ to $33.0^{\circ} \mathrm{C}$ (Table 2).

\subsection{Hydrolysis of Cassava Peel}

The concentration of $\mathrm{HCN}$ increased from 0.2 to $0.87 \mathrm{mg} \mathrm{HCN} \mathrm{L}^{-1}$ as the enzyme hydrolysis progressed for a period of $9 \mathrm{~h}$, whereas acid hydrolysis gave a $\mathrm{HCN}$ level of $0.82 \mathrm{mg} \mathrm{HCN} \mathrm{L}{ }^{-1}$ after $0.6 \mathrm{~h}$.

\subsection{Growth Parameters of C. utilis Grown in Cassava Peel Hydrolysates}

The growth of $C$. utilis in the acid and enzymatic hydrolysates was exponential up to the point of carbohydrate depletion (Fig. 4). The maximum specific growth rate $\left(\mu_{\max }\right)$, maximum volumetric rates of yeast protein production $\left(\mathrm{Q}_{\mathrm{p}}{ }^{\mathrm{max}}\right)$ and sugar uptake $\left(\mathrm{Q}_{\mathrm{s}}{ }^{\mathrm{max}}\right)$, and the yields of cell mass and yeast protein were higher in the acid hydrolysate than in the enzymatic hydrolysate (Table 3). The greater amount of cyanide released during enzymatic hydrolysis of the cassava peel relative to acid hydrolysis (see above section 3.3) might have contributed to these lower values recorded in the enzymatic hydrolysate. C. utilis utilized the sugars efficiently with virtually no residual sugars after 7 to $8 \mathrm{~h}$ of cultivation (Fig. 4). From Fig. 4A it is evident that maltose utilization was inhibited by glucose metabolism.

The above yields and growth rates (Table 3 ) are in accordance with values found by others for $C$. utilis. The biomass yield coefficients on glucose reported in the literature range from 0.45 to 0.55 [29, 34, 39], whereas Moreton [35] reported $\mathrm{Y}_{\mathrm{x} / \mathrm{s}}$ values of 0.51 to 0.58 for the growth of $C$. utilis on enzymatically hydrolysed potato waste starch.

\subsection{Composition of C. utilis Grown in Cassava Peel Hydrolysates and on Glucose}

The chemical composition of $C$. utilis biomass grown in cassava peel hydrolysates and on glucose, and the corresponding amino acid profiles, are presented in Tables 4 and 5 . The yeast protein content on a dry biomass basis ranged from $47.5 \%$ on glucose to $56.65 \%$ in enzymatic hydrolysate. The protein content of the biomass grown in the hydrolysates was significantly $(P$ $\leq 0.05$ ) greater than that of cells grown on glucose. As expected, no cyanide was detected in the $C$. utilis cells grown on glucose. The cyanide concentration in yeast cells cultivated in enzymatic hydrolysate was higher than found in cells grown in the acid hydrolysate, namely $0.68 \pm 0.02$ and $0.52 \pm 0.05 \mathrm{mg}$ per $100 \mathrm{~g}$ dry cell mass, respectively. However, these cyanide levels were below the deleterious level of $30 \mathrm{mg} \mathrm{kg}^{-1}$ [40].

The amino acids profiles (Table 5) were comparable to those previously reported for strains of Saccharomyces, Kluyveromyces and Candida [41, 42] and compared favourably with the FAO standard with methionine as the limiting amino acid.

The methionine content in C. utilis cells from the acid hydrolysate was $39.45 \%$ on a dry weight basis, $16.50 \%$ in biomass from the enzymatic hydrolysate and $32.15 \%$ in biomass grown in the mineral salts medium on glucose (Table 6).

These results agreed with the observation that yeast protein was characteristically low in sulphur-containing amino acids [43]. 


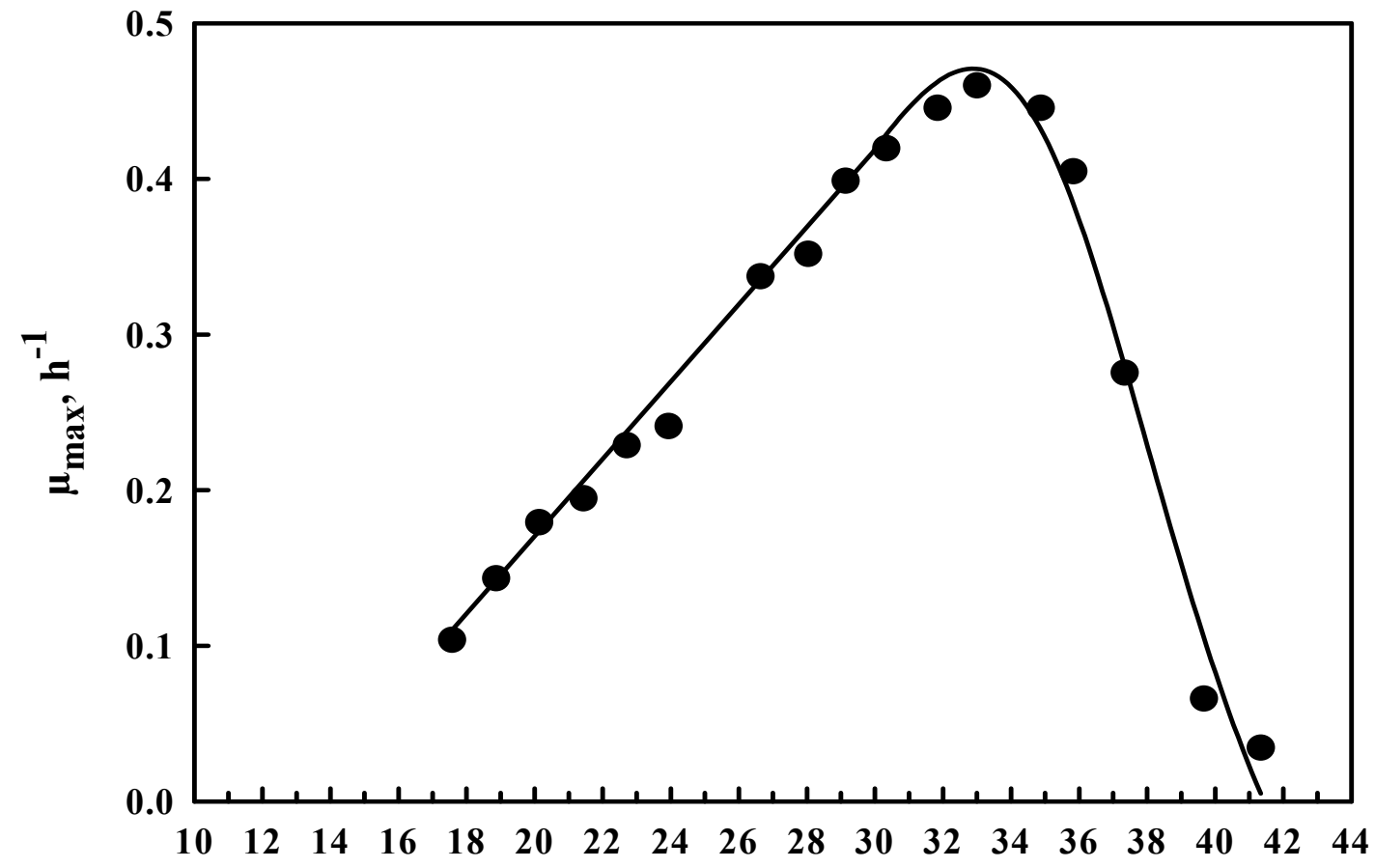

Temperature, ${ }^{\circ} \mathrm{C}$

Fig. 2 Effect of cultivation temperature on the maximum specific growth rate $\left(\mu_{\max }\right)$ of $C$. utilis.

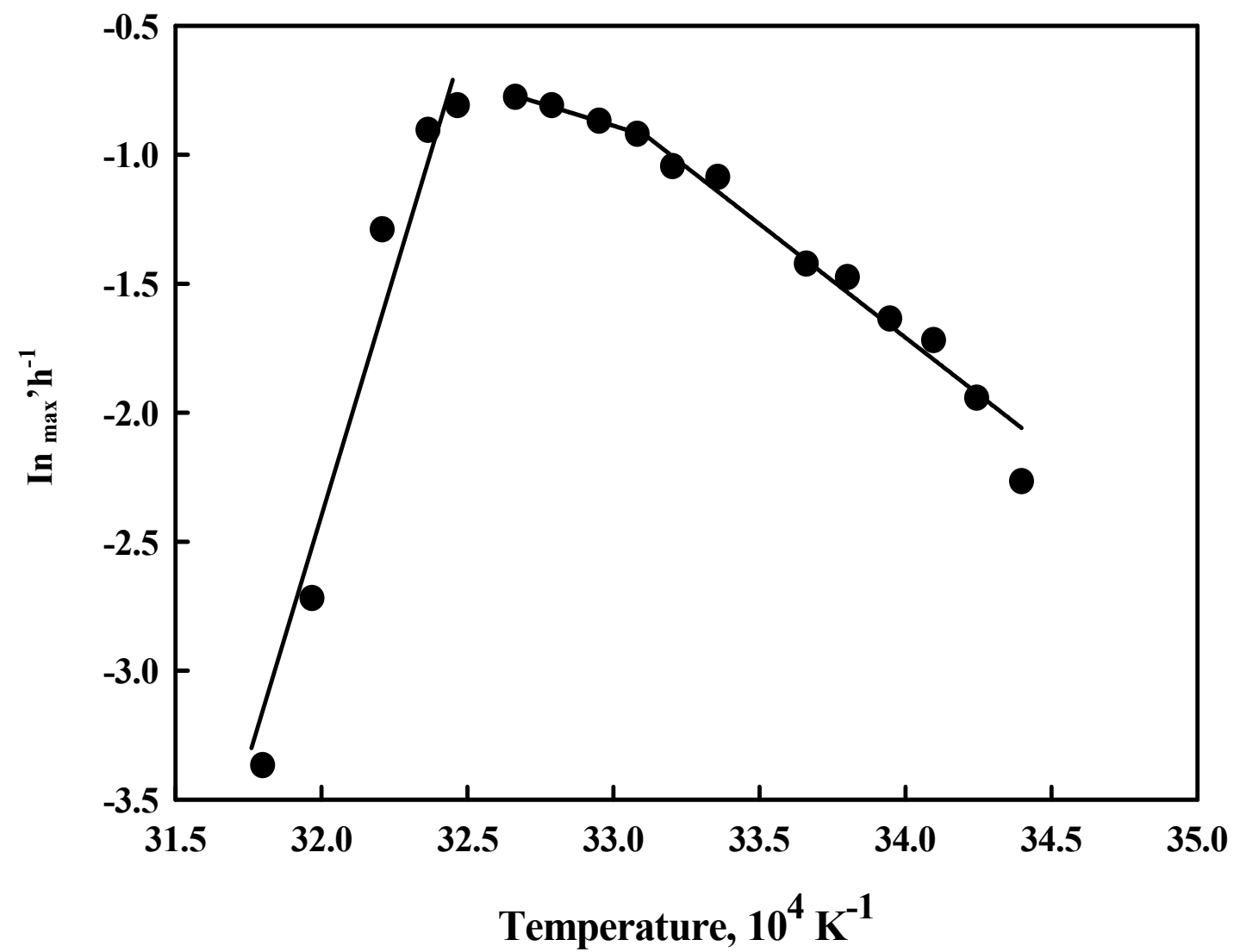

Fig. 3 Arrhenius plot of the relationship between the maximum specific growth rate $\left(\mu_{\max }\right)$ of $C$. utilis and cultivation temperature, calculated from the data of Fig. 2. 


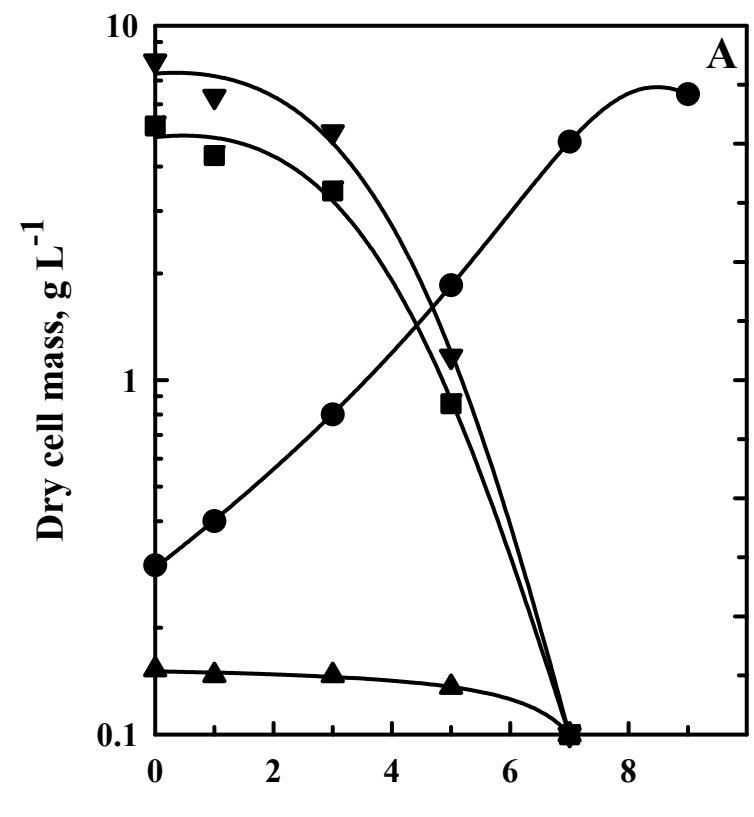

Cultivation time, $h$

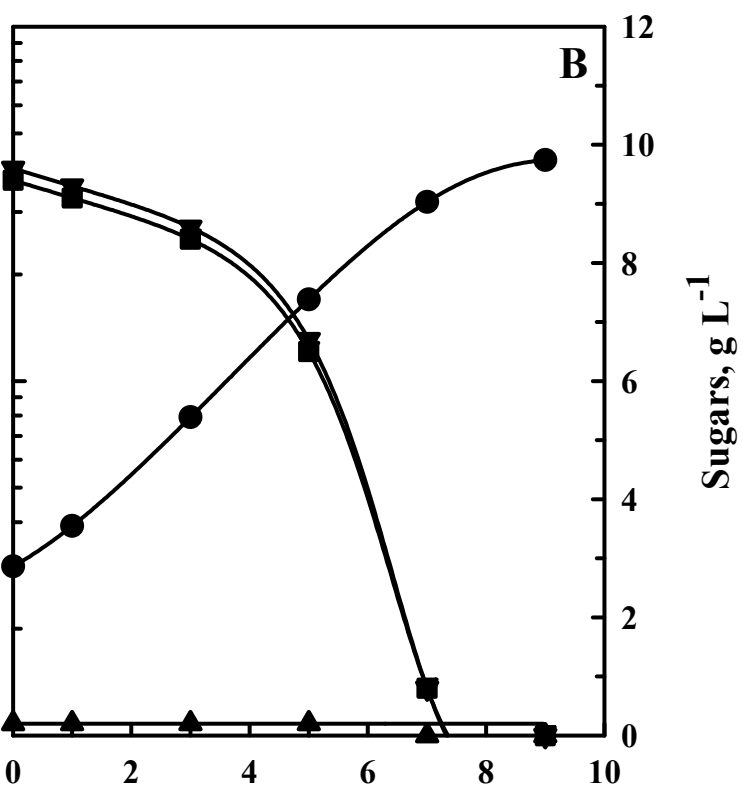

Cultivation time, $h$

Fig. 4 Growth curves and sugar utilization of $C$. utilis in an acid (A) and enzymatic (B) hydrolysate of cassava peel. Symbols: dry cell mass $(\bullet)$, glucose $(\square)$, maltose $(\Delta)$, glucose plus maltose $(\nabla)$.

Table 3 Cultivation parameters of $C$. utilis during bioreactor cultivation in cassava peel hydrolysates.

\begin{tabular}{lll}
\hline Parameter $^{1}$ & Acid hydrolysate & $\begin{array}{l}\text { Enzymatic } \\
\text { hydrolysate }\end{array}$ \\
\hline$\mu_{\max } / h^{-1}$ & $0.48( \pm 0.01)$ & $0.35( \pm 0.01)$ \\
$\mathrm{Q}_{\mathrm{p}}{ }^{\max } / \mathrm{g} \mathrm{L}^{-1} \mathrm{~h}^{-1}$ & $0.32( \pm 0.03)$ & $0.21( \pm 0.04)$ \\
$\mathrm{Q}_{\mathrm{s}}{ }^{\max } / \mathrm{g} \mathrm{L}^{-1} \mathrm{~h}^{-1}$ & $1.60( \pm 0.5)$ & $1.20( \pm 0.4)$ \\
$\mathrm{Y}_{\mathrm{x} / \mathrm{s}} / \mathrm{g} \mathrm{cells} \mathrm{g}^{-1}$ substrate & $0.52( \pm 0.1)$ & $0.44( \pm 0.2)$ \\
$\begin{array}{l}\text { utilized } \\
\mathrm{Y}_{\mathrm{p} / \mathrm{s}} / \mathrm{g} \text { yeast protein } \mathrm{g}^{-1}\end{array}$ & $0.26( \pm 0.1)$ & $0.21( \pm 0.2)$ \\
substrate utilized &
\end{tabular}

Values are expressed on a dry mass basis. Each value is the mean of three independent experiments, with the standard deviation of the mean indicated in parentheses.

Table 4 Chemical composition of $C$. utilis biomass grown in cassava peel hydrolysates and on glucose.

\begin{tabular}{|c|c|c|c|}
\hline Component $(\%)^{1}$ & $\begin{array}{l}\text { Acid } \\
\text { hydrolysate }\end{array}$ & $\begin{array}{l}\text { Enzymatic } \\
\text { hydrolysate }\end{array}$ & Glucose \\
\hline Crude protein & $49.1( \pm 0.5)$ & $56.7( \pm 0.7)$ & $47.5( \pm 0.8)$ \\
\hline True protein & $47.0( \pm 0.9)$ & $53.5( \pm 0.5)$ & $43.6( \pm 0.3)$ \\
\hline $\mathrm{HCN} / \mathrm{mg} 100 \mathrm{~g}^{-1}$ & $0.52( \pm 0.05)$ & $0.68( \pm 0.02)$ & 0 \\
\hline Ash & $1.38( \pm 0.04)$ & $0.88( \pm 0.1)$ & $0.71( \pm 0.2)$ \\
\hline Carbohydrates & $48.9( \pm 0.6)$ & $42.3( \pm 0.8)$ & $51.5( \pm 1.1)$ \\
\hline Ether extract & $0.63( \pm 0.05)$ & $0.20( \pm 0.03)$ & $0.31( \pm 0.04)$ \\
\hline Crude fibre & $1.44( \pm 0.12)$ & $1.14( \pm 0.18)$ & $1.82( \pm 0.15)$ \\
\hline
\end{tabular}

Values are expressed as a percentage of the dry biomass, except for $\mathrm{HCN}$. Each value is the mean of three independent experiments, with the standard deviation of the mean indicated in parentheses.
Table 5 Amino acid profiles of $C$. utilis biomass grown in cassava peel hydrolysates and on glucose.

\begin{tabular}{llll}
\hline Amino Acid $^{1}$ & $\begin{array}{l}\text { Acid } \\
\text { hydrolysate }\end{array}$ & $\begin{array}{l}\text { Enzymatic } \\
\text { hydrolysates }\end{array}$ & Glucose \\
\hline Aspartic acid & $3,721( \pm 35)$ & $3,608( \pm 32)$ & $3,573( \pm 35)$ \\
Threonine & $1,524( \pm 26)$ & $1,604( \pm 24)$ & $1,581( \pm 21)$ \\
Serine & $1,331( \pm 22)$ & $338( \pm 21)$ & $1,231( \pm 22)$ \\
Glutamic acid & $7,096( \pm 16)$ & $6,464( \pm 15)$ & $8,006( \pm 18)$ \\
Glycine & $1,930( \pm 11)$ & $1,957( \pm 12)$ & $1,877( \pm 11)$ \\
Alanine & $2,377( \pm 13)$ & $2,257( \pm 13)$ & $2,752( \pm 12)$ \\
Valine & $2,110( \pm 13)$ & $2,197( \pm 15)$ & $2,375( \pm 14)$ \\
Methionine & $426( \pm 7)$ & $206( \pm 8)$ & $336( \pm 9)$ \\
Isoleucine & $1,944( \pm 12)$ & $1,990( \pm 13)$ & $2,045( \pm 14)$ \\
Leucine & $2,982( \pm 23)$ & $3,009( \pm 28)$ & $3,041( \pm 31)$ \\
Tyrosine & $859( \pm 11)$ & $879( \pm 12)$ & $821( \pm 11)$ \\
Phenylalanine & $1,624( \pm 13)$ & $1,651( \pm 13)$ & $1,662( \pm 11)$ \\
Histidine & $1,005( \pm 10)$ & $1,052( \pm 11)$ & $1,164( \pm 12)$ \\
Lysine & $2,363( \pm 14)$ & $2,610( \pm 15)$ & $2,516( \pm 14)$ \\
Arginine & $2,556( \pm 16)$ & $2,536( \pm 18)$ & $3,088( \pm 16)$ \\
Total content & 33,852 & 33,358 & 36,069 \\
Total content, \% & 33.9 & 33.4 & 36.1
\end{tabular}

Values are expressed as mg amino acids per $100 \mathrm{~g}$ dry biomass. Each value is the mean of three independent experiments, with the standard deviation of the mean indicated in parentheses.

\section{Conclusions}

Candida utilis grew well and utilised sugars efficiently for protein production in acid and enzymatic 
Table 6 Chemical score of $C$. utilis biomass protein grown in cassava peel hydrolysates and on glucose.

\begin{tabular}{|c|c|c|c|c|c|c|c|}
\hline Amino acid & $\begin{array}{l}\mathrm{FAO} / \mathrm{WHO} \\
\text { amino acid } \\
\text { pattern }\left(\mathrm{mg} \mathrm{g}^{-1}\right)\end{array}$ & $\begin{array}{l}\text { Biomass from Acid } \\
\text { hydrolysate, amino } \\
\text { acid }\left(\mathrm{mg} \mathrm{g}^{-1}\right)\end{array}$ & $\begin{array}{l}\text { Amino acid, } \\
\text { acid } \\
\text { hydrolysate } \\
(\%)\end{array}$ & $\begin{array}{l}\text { Biomass from } \\
\text { enzymatic } \\
\text { hydrolysate, amino } \\
\text { acid }\left(\mathrm{mg} \mathrm{g}^{-1}\right)\end{array}$ & $\begin{array}{l}\text { Amino acid, } \\
\text { enzymatic } \\
\text { hydrolysate } \\
(\%)\end{array}$ & $\begin{array}{l}\text { Biomass } \\
\text { from glucose, } \\
\text { amino acid } \\
\left(\mathrm{mg} \mathrm{g}^{-1}\right)\end{array}$ & $\begin{array}{l}\text { Amino } \\
\text { acid, } \\
\text { glucose } \\
(\%)\end{array}$ \\
\hline Threonine & 28 & 31.04 & 90.21 & 28.29 & 101.04 & 33.28 & 118.85 \\
\hline Valine & 42 & 42.97 & 102.30 & 38.75 & 92.26 & 50.00 & 119.05 \\
\hline Methionine & 22 & 8.68 & 39.45 & 3.63 & 16.5 & 7.073 & 32.15 \\
\hline Isoleucine & 42 & 39.59 & 94.26 & 35.10 & 83.57 & 43.05 & 102.5 \\
\hline Leucine & 48 & 60.73 & 165.52 & 53.07 & 110.56 & 64.02 & 133.38 \\
\hline Phenylalanine & 28 & 33.08 & 118.14 & 29.12 & 104 & 34.99 & 124.96 \\
\hline Lysine & 42 & 48.13 & 114.60 & 46.03 & 109.54 & 53.92 & 128.38 \\
\hline Chemical Score & & & 39.45 & & 16.50 & & 32.15 \\
\hline Limiting amino acid & & & Methionine & & Methionine & & Methionine \\
\hline
\end{tabular}

hydrolysates of cassava peel. C. utilis grown on this starchy food processing waste has potential for use as a protein supplement in food and feed and provides a practical means of utilizing such wastes from cassava processing. One of the major limiting factors in the large scale production of SCP for human and feed consumption is the high cost of suitable substrates that can serve as carbon source. According to this study, this can be mitigated by the use of cheap and easily available food processing wastes such as cassava peel.

\section{Acknowledgments}

This work was supported by the John D. and Catherine T. MacArthur Foundation Grant awarded to O.O. Ezekiel and was undertaken in the Department of Microbial, Biochemical and Food Biotechnology, University of the Free State, Bloemfontein, South Africa.

\section{References}

[1] IUPAC, Compedium of Chemical Terminology, 2nd ed., International Union of Pure and Applied Chemistry, 1997.

[2] C.R. Kuhad, A. Singh, K.K. Tripathi, R.K.Saxena, K.L. Eriksson, Microorganisms as an alternative source of protein, Nutr. Rev. 55 (1997) 65-75.

[3] M.I. Rajoka, Production of single cell protein through fermentation of a perennial grass grown on saline lands with Cellulomonas biazotea, World J. Microbiol. Biotechnol. 21 (2005) 207-211.

[4] E. Rosenberg, Exploiting microbial growth on hydrocarbons: new markets, Trends Biotechnol. 11 (1993) 419-424.
[5] T. Hongpattarakere, A. H-Kittikun, Optimization of single cell-protein production from cassava starch using Schwanniomyces castelli, World J. Microbiol. Biotechnol. 11 (1995) 607-609.

[6] D. Paul, R. Mukhopadhyay, B.P. Chatterjee, A.K. Guha, Nutritional profile of food yeast Kluyveromyces fragilis biomass grown on whey, Appl. Biochem. Biotechnol. 97 (2002) 209-218.

[7] A.E. Ghaly, R.M.B. Hassan, Continuous production of single cell protein from cheese whey by Kluyveromyces frtagilis, Transactions of the ASAE 38 (4) (1995) 1113-1120.

[8] A.E. Ghaly, R.M.B. Hassan, N. Ben-Abdallah, Utilization of cheese whey lactose by Kluyveromyces fragilis for growth and energy under continuous conditions, Appl. Biochem. Biotechnol. 36 (1992) 301-322.

[9] M. Moresi, A. Truufio, E. Parente, Kinetics of continuous whey fermentation by Kluyveromyces fragilis, J. Chem. Technol. Biotechnol. 49 (1990) 205-222.

[10] J.B. Mickle, W. Smith, D. Halter, S. Knight, Perfomance and morphology of Kluyveromyces fragilis and Rhodotorula gracilis grown in cottage cheese whey, J. Milk Food Technol. 37 (1974) 481-484.

[11] A.E. Ghaly, M. Kamal, L.R. Correia, Kinetic modelling of continuous submerged fermentation of cheese whey for single cell protein production, Bioresour. Technol. 96 (2005) 1143-1152.

[12] N. Schultz, L. Chang, A. Hauck, M. Reuss, C. Syldatk, Microbial production of single-cell protein from deproteinized whey concentrate, Appl. Microbiol. Biotechnol. 6 (2006) 515-520.

[13] B. Gohl, Tropical Feeds, FAO/Oxford Computer Journals Ltd., Version 1.7, 1991.

[14] M.A. Olvera-Novoa1, C.A. Martínez-Palacios, I. Olivera-Castillo, Utilization of torula yeast (Candida utilis) as a protein source in diets for tilapia (Oreochromis mossambicus Peters) fry, Aquacult. Nutr. 8 (2002) 257-264. 
[15] M.F. Payne, R.J. Rippingale, Evaluation of diets for culture of calanoid copepod Gladioferens imparipes, Aquaculture 187 (2000) 85-96.

[16] G.L. Rumsey, R.A. Winfree, S.G. Hughes, Nutritional value of dietary nucleic acids and purine bases to rainbow trout (Oncorynchus mykiss), Aquaculture 108 (1992) 97-110.

[17] R. Macrae, R.K. Robinson, M.T. Sadle, Encyclopedia of Food Science, Food Technology and Nutrition, Academic Press, 1993, pp. 4835-4836.

[18] E.A. Iyayi, D.M. Losel, Protein enrichment of cassava by-products through solid state fermentation by fungi, J. Food Technol. Afr. 6 (2001) 116-118.

[19] B. Nestel, Current utilization and future potential for cassava, in: B. Nestel, R. Macintyre (Eds.), Chronic Cassava Toxicity, International Development Centre, Ottawa, 1973, pp. 11-26.

[20] D. Subrahmanyan, Processing: Fermented foods of cassava, Food Laboratory News No. 21 (1990) 9-12.

[21] I.A. Akinrele, Hydrocyanic hazard during large scale cassava processing, Trop. Sci. 26 (1986) 59-65.

[22] E. Giraud, A. Brauman, S. Keleke, B. Lelong, M. Raimbult, Isolation and physiological study of an amylolytic strain of Lactobacillus plantarum, Appl. Microbiol. Biotechnol. 36 (1991) 379-383.

[23] A.A. Onilude, Effect of cassava cultivar, age and pretreatment processes of cellulase and xylanase production from cassava waste by Trichoderma harzanium, J. Basic Microbiol. 36 (1996) 421-431.

[24] E.A. Iyayi, O.O. Tewe, Effect of protein deficiency in utilization of cassava peel by growing pigs, in: S.K. Haha, L. Reynolds, G.N. Egbunike (Eds.), Cassava as Livestock feed in Africa, Proceedings of the IITA/ILCA/University of Ibadan workshop, Nov. 14-18, 1988, pp. 54-59.

[25] S.K. Hahn, J. Keyser, Cassava: A basic food in Africa, Outlook Agric. 4 (1985) 95-100.

[26] J.C. du Preez, J.P. van der Walt, Fermentation of D-xylose to ethanol by a strain of Candida shehatae, Biotechnol. Lett. 5 (1983) 357-362.

[27] A.L. Woiciechowski, S. Nitsche, A. Pandey, C.R. Soccol, Acid and enzymatic hydrolysis to recover reducing sugar from cassava bagasse: An economic study, Braz. Arch. Biol. and Technol. 45 (2002) 393-400.

[28] J.C. du Preez, D.F. Toerien, The effect of temperature on the growth of Acetobacter calcoaceticus, Water SA. 4 (1978) 10-13.

[29] S.J. Pirt, Principles of Microbe and Cell Cultivation, Blackwell Scientific Publications, Oxford, 1975.
[30] L.H. Stickland, The determination of small quantities of bacteria by means of the biuret reaction, J. Gen. Microbiol. 5 (1951) 698-703.

[31] AOAC, Official methods of analysis, 13th ed., Association of Official Analytical Chemists, Washington, DC. 1990.

[32] R.D. Cooke, An enzymatic assay for total cyanide content of cassava (manihot esculanta Crantz), J. Sci. Food Agric. 29 (1978) 345-352.

[33] FAO/WHO, Ad hoc Expert "Committe, Energy and Protein requirements": World Health Publishing Co., 1957, pp. 35-36.

[34] M. Tobajas, E. Garciá-Calvo, Comparison of analysis methods for determination of the kinetics in batch cultures, World J. Microbiol. Biotechnol. 16 (2000) 845-851.

[35] R.S. Moreton, Growth of Candida utilis on enzymatically hydrolysed potato waste, J. Appl. Bacteriol. 44 (1978) 373-382.

[36] E. Postma, C. Verduyn, W.A. Scheffers, J.P. van Dijken, Enzymatic analysis of the Crabtree effect in glucose limited cultures of Saccharomyces cerevisiae, Appl. Environ. Microbiol. 53 (1989) 368-477.

[37] J.M. Peinado, A. Barbero, C. Nombela, Starch biodegradation by yeast: Glucose effects and utilization of other ends products of starch hydrolysis, in: O.M. Neissel, R.R. van der Meer, K.C.A.M. Luyben (Eds.), Proceedings of the 4th European Congress on Biotechnology, Elsevier Science Publishers, the Netherlands, 1987, pp. 528-530.

[38] H.M. Musenges, J.G. Anderson, R.S. Holdom, Growth of Candida utilis on enzymatically hydrolysed cassava, Biotechnol. Lett. 2 (1980) 35-40.

[39] D. Herbert, Stoichiometric aspects of microbial growth, in: A.C.R. Dean, D.C. Ellwood, C.G.T. Evans, J. Melling (Eds.), Continuous Culture 6, Ellis Horwood, Chichester, 1976, pp. 1-30.

[40] R. Tweyongyere, I. Katongole, Cyanogenic potential of cassava peels and their detoxification for utilization as livestock feed, Vet. Hum. Toxicol. 44 (2002) 366-369.

[41] V. Apaire, J.P. Guiraud, P. Galzy, Selection of yeasts for single cell protein production on media based on Jerusalem artichoke extracts, Z. Allg. Mikrobiol. 23 (1983) 211-218.

[42] A.E.V. Martini, M.W. Miller, A. Martini, Amino acid composition of whole cells of different yeasts, J. Agric. Food Chem. 27 (1979) 982-984.

[43] P.J. Anderson, K.E. McNeil, K. Watson, Thermotolerant single cell protein production by Kluyveromyces marxianus var. marxianus, J. Ind. Microbiol. 3 (1988) 9-14. 